\title{
Evaluating pre-service science teachers' concept mastery in the topic of biodiversity during distance learning under circumstance of Covid-19 pandemic
}

\author{
Aida Fikriyah ${ }^{1}$ *, Bayu Sandika ${ }^{2}$, Etistika Yuni Wijaya ${ }^{1}$ \\ ${ }^{1}$ Department of Natural Science Education, Faculty of Education, Universitas Trunojoyo Madura. \\ Jl. Raya Telang, Telang, Kamal, Kabupaten Bangkalan, Jawa Timur 69162, Indonesia \\ ${ }^{2}$ Department of Biology Education, Institut Agama Islam Negeri Jember. \\ Jl. Mataram No.1, Mangli, Jember, Jawa Timur 68136, Indonesia \\ * Coressponding Author. E-mail: aida.fikriyah@trunojoyo.ac.id
}

Received: 11 October 2020; Revised: 8 December 2020; Accepted: 20 December 2020

\begin{abstract}
Students as pre-service science teachers have to reach concept mastery during learning process, since it includes in a teachers' pedagogical competence that has to be attained well. Although this current circumstance is under covid-19 pandemic, the distance learning should provide an effective situation that can gauge students' concept mastery. This study aims at evaluating pre-service science teachers' concept mastery in the topic of biodiversity during distance learning under circumstance of covid-19 pandemic. The research included in a descriptive quantitative study. The distance learning was conducted in the lecture of bioconservation during odd semester, on September 2020 toward 50 students in the year academic of 2017. Data were collected using an online test consisting of 10 multiple choice questions. Findings indicates that the preservice science teachers' concept mastery reached a score of 53.0 in which was categorized as moderate criteria. Therefore, it can be concluded that the concept mastery has to be enhanced continually in every learning process in order pre-service science teachers are able to comprehend science concepts and enhance this mastery respectively.
\end{abstract}

Keywords: biodiversity, concept mastery, covid-19 pandemic, distance learning.

How to Cite: Fikriyah, A., Sandika, B., \& Wijaya, E. (2020). Evaluating pre-service science teachers' concept mastery in the topic of biodiversity during distance learning under circumstance of Covid-19 pandemic. Jurnal Inovasi Pendidikan IPA, 6(2), 209-216. doi:https://doi.org/10.21831/jipi.v6i2.35033

\section{INTRODUCTION}

Science as the body of knowledge discusses about life and its phenomenon. Science also contains of structure and process of the physical, chemical, and biological which can be carried out through investigation activities (Costa \& Araujo, 2018). Furthermore, science learning presents facts, concepts, principles, laws, hypotheses, theories, and models (Müller et al., 2016; Rusilowati et al., 2015). Science also represents the investigative nature which reflects the process of scientific method such as observing, identifying, measuring, classifying, inferring, analyzing data, making calculations, and concluding (Fratiwi et al., 2019; Saprudin et al., 2020).

Science also acts as a way of thinking which represents a process of thinking, reasoning, reflecting, and creating scientific attitudes and skills. (Gumilar \& Wardani, 2020; Rosamsi et al., 2019) One of topics that have to be learned in science is biodiversity. Biodiversity contains of concepts about diversities of living thing including its genes, its classification, and its interaction with environment (Littenberg-Tobias \& Reich, 2020). This topic contains of plenty complex concepts that have to be mastered well by learners. Therefore, science is very significant to be learned by learners at schools and universities. However, science learning not only aims at transmitting science knowledge and information to learners but also enhancing its concept mastery (Prabowo et al., 2020; Satriawan et al., 2019). Concept mastery is defined as the process of learners in comprehending certain concepts. Pre-service science tachers have to reach concept mastery since they will use it later when they teach in the class (Nugroho \& Suryadarma, 2018).

Regardless, the success of science learning and teaching process is strongly influenced by the educators' competences and the learning process (Rahayu, 2017). As it is already stated that teachers' 


\section{Jurnal Inovasi Pendidikan IPA, 6 (2), 2020 - 210}

Aida Fikriyah, Bayu Sandika, Etistika Yuni Wijaya

competencies includes pedagogical, personal, social, and professional. Pre-service science teachers have to master those four competencies, so that they are easily to create a learning design as expected. The successful learning also depnds on standard design learning that is conducted in which ensuring learners in participating during learning activities (Prabowo et al., 2020; Sadiqin et al., 2017).

Students as pre-service science teachers have to master science concepts. If they do so, therefore it will be easy when they are going to teach at the class. It is already explained that the concept mastery is related to pedagogical knowledge (Tamimiya \& Suryadarma, 2019; Widiyawati \& Nurwahidah, 2018). This knowledge has to be attained by students as pre-service science teachers. One of the ways to reach this knowledge is students have to understand the subject matter. However, during the learning process, students will catch various problems and challenges in comprehending concepts. As we know, science concepts mostly exemplify common instable structures of information, objects, principles, ideas, and activities (Badriyah et al., 2020). Furthermore, students also improve the concept comprehension at an early development when they undergo thinking and learning process, in which it can generate huge problem if the concepts that they understand are diverse from scientific considerations, this phenomenon is referred to as misconception (Goodsett, 2020; van Rensburg, 2018). This phenomenon should be minimized in order learners as pre-service science teachers can perform well in pedagogical knowledge.

In addition, if the concepts have been mastered well, learners can apply the concepts actively, by creating and realating the concepts to daily life. By working through various processes, creating different causes and effects, the learners are able to fully understand their own role in bringing about the consequences of their behavior, and fully understand what they can do differently if they desire different results (Kumari et al., 2020; Littenberg-Tobias \& Reich, 2020). Furthermore, scientific pheno-menon are ubiquitous in students' everyday lives. Educators have to provide the varying experiences and prerequisites for learning in every learner's background (Mamun et al., 2020). Educators also have to ensure that classroom instructional quality is critical, because it provides the opportunity to foster students' domain knowledge and specific learning processes and to develop comcept mastery systematically (van Rensburg, 2018).

Pre-service science teachers should be prepared to be ready to think, solve problems, analyze challenges, make innovations, and decide conclusions. However, these skills are considered difficult to be taught and developed, so they are rarely deliberately included in the learning process. Outstandingly, these skills are crucial for all students today in facing challenges in the era of globalization and important for them when they will go teaching in a class (Afandi et al., 2019; Rusli et al., 2020). Therefore, educators have to ensure to develop pre-service science teachers in the future to be able to have concept mastery. As a consequence, pre-service science teachers are the most influential factor to transfer the science knowledge to students in learning process so that concept mastery have to be developed well.

As captured in the previous PISA 2015 assessment, educators have to explain how a science idea can be applied to a number of different phenomena (OECD, 2018). Educators also have to explain scientific ideas so that learners are easily to comprehend certain concepts. The quality of science teaching and learning process is also linked to the process of the way of educators teach, and the methods that they use to provide effective science learning process (Glaze, 2018; Jeong \& González-Gómez, 2020). However, the current condition is under covid-19 global pandemic in which the government in many countries outfits rules that limit people coming together in public places (König et al., 2020). This rule impacts on learning process at schools and universities in which students and educators cannot attend the places and have face-to-face learning activities like before (Reimers et al., 2020). Additionally, the science learning process is conducted in distance.

Distance learning offers new learning experiences both for students and educators. During distance learning process, learners are able to study actively and responsibly. Students are also able to increase higher thinking during the online learning, because it provides a plenty of information that can serve as a flexible substitute for distance learning process (Kumari et al., 2020; Rapanta et al., 2020). Furthermore, by having distance learning, students can undergo best learning practice that leads to concept mastery. In contrast, for educators, distance learning offers essential adaptive challenges, in which they have to provide effective learning environments although in online form.

In addition, distance learning can be much more self-paced, allowing learners to evaluate and reflect more carefully on their interactions and assignments. An online learning process also can encourage learners to develop social interaction, identify important knowledge, avoid useless information, and develop skills (Goodsett, 2020; Kumari et al., 2020). Distance learning also can provide students as 
pre-service science teachers' valuable experiences by addressing individual differences, providing hands-on activities, encouraging students to have reflection, constructing a real-life context, and motivating them selves individually and actively (Littenberg-Tobias \& Reich, 2020). Therefore, although the learning process is conducted in distance, the learners' concept mastery has to be developed gradually.

According to those previous views, this study aimed at evaluating pre-service science teachers' concept mastery in the topic of biodiversity during distance learning under circumstance of covid-19 pandemic.

\section{METHOD}

This study includes in a descriptive quantitative research. It is a descriptive quantitative since it described current conditions, used specific samples, and used a test to gauge the concept mastery. This research was conducted during odd semester in the academic year of 2020-2021, exactly on September 2020. The distance learning process was implemented asynchronously in the lecture of bioconservation toward 49 students from class A in the academic year of 2017 from a public university in Indonesia. The students in this class consisted of six boys and 43 girls.

This current study relies on a test-given technique to collect data. Tests given to the pre-service science teachers were used to evaluate students' concept mastery. The pre-service science teachers' concept mastery was assessed using an online test in the application of google form, consisting of ten multiple choice questions related to concept of biodiversity. The test of concept mastery contains of five indicators; defining, giving examples, classifying, explaining, and concluding. Furthermore for every indicator consists of two questions.

The test instrument has been validated and reviewed by two lecturers before given to students. The validation evaluated about the aspect of content in the test instrument. The results of validation revealed that the test instrument can be used to assess the pre-service science teachers' concept mastery. Furthermore, the test instrument was filled out the by students for 45 minutes individually. Score of concept mastery in every pre-service science teacher that has been obtained was categorized based on criteria in the Table 1.

Table 1. Category of concept mastery

\begin{tabular}{cc}
\hline Score & Category \\
\hline $85.0-100$ & Very high \\
$70.0-84.9$ & High \\
$55.0-69.9$ & Moderate \\
$40.0-54.9$ & Low \\
$0-39.9$ & Very low \\
\hline
\end{tabular}

\section{RESULTS AND DISCUSSION}

In this study, pre-service science teachers' concept mastery in the topic of biodiversity during distance learning under circumstance of covid-19 pandemic was gauged using an online test. Furthermore, the score of pre-service science teachers' concept mastery can be seen in the Table 2, meanwhile the number of pre-service science teachers who reach every category is presented in the Figure 1.

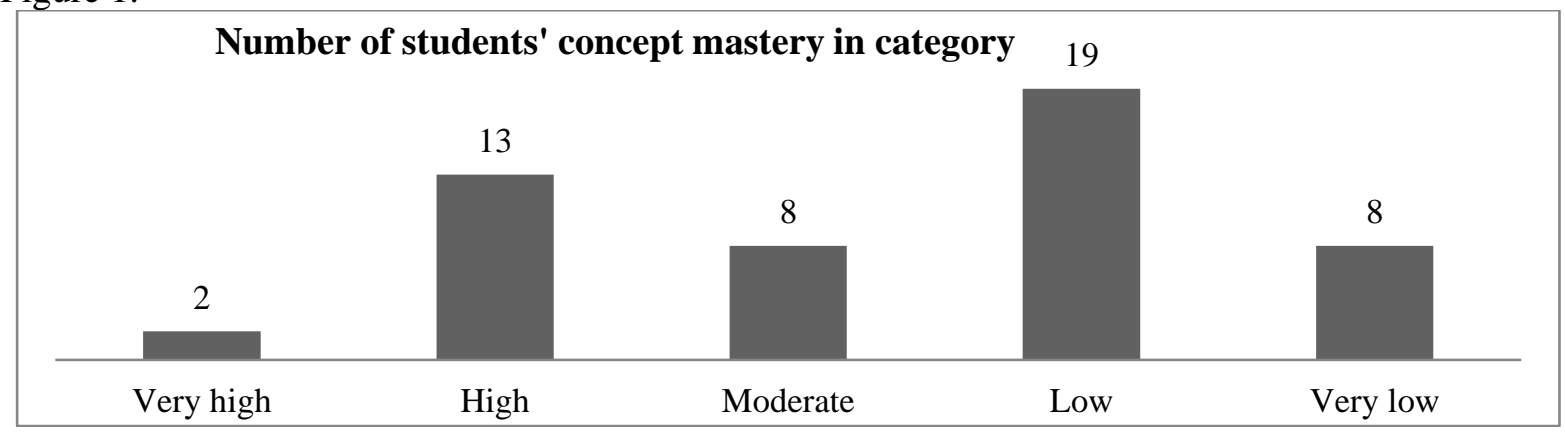

Figure 1. Number of pre-service science teachers' concept mastery in category 


\section{Jurnal Inovasi Pendidikan IPA, 6 (2), 2020 - 212}

Aida Fikriyah, Bayu Sandika, Etistika Yuni Wijaya

According to the findings on Table 2, it can be assumed that pre-service science teachers' concept mastery reached a moderate level, showing 53.0 on the average of a score. It also can be seen from Figure 1 that from out of 50 students, there were 19 students reached low concept mastery. Meanwhile, 13 students reached high concept mastery. Eight students reached moderate concept mastery. Furthermore, the other eight students reached very low concept mastery and only two pre-service science teachers reached very high concept mastery.

Table 2. Score of pre-service science teachers' concept mastery

\begin{tabular}{|c|c|c|}
\hline Name & Score & Category \\
\hline A1 & 50,0 & Low \\
\hline A2 & 60,0 & Moderate \\
\hline A3 & 70,0 & High \\
\hline A4 & 50,0 & Low \\
\hline A5 & 80,0 & High \\
\hline A6 & 40,0 & Low \\
\hline A7 & 30,0 & Very low \\
\hline A8 & 80,0 & High \\
\hline A9 & 80,0 & High \\
\hline A10 & 40,0 & Low \\
\hline A11 & 80,0 & High \\
\hline A12 & 40,0 & Low \\
\hline A13 & 50,0 & Low \\
\hline A14 & 40,0 & Low \\
\hline A15 & 60,0 & Moderate \\
\hline A16 & 90,0 & Very high \\
\hline A17 & 80,0 & High \\
\hline A18 & 50,0 & Low \\
\hline A19 & 40,0 & Low \\
\hline A 20 & 40,0 & Low \\
\hline A21 & 40,0 & Low \\
\hline A22 & 60,0 & Moderate \\
\hline A23 & 80,0 & High \\
\hline A24 & 30,0 & Very low \\
\hline A25 & 40,0 & Low \\
\hline A26 & 70,0 & High \\
\hline A27 & 80,0 & High \\
\hline A28 & 70,0 & High \\
\hline A29 & 60,0 & Moderate \\
\hline A30 & 80,0 & High \\
\hline A31 & 50,0 & Low \\
\hline A32 & 60,0 & Moderate \\
\hline A33 & 20,0 & Very low \\
\hline A34 & 40,0 & Low \\
\hline A35 & 60,0 & Moderate \\
\hline A36 & 90,0 & Very high \\
\hline A37 & 40,0 & Low \\
\hline A38 & 20,0 & Very low \\
\hline A39 & 70,0 & High \\
\hline A40 & 50,0 & Low \\
\hline A41 & 60,0 & Moderate \\
\hline A42 & 40,0 & Low \\
\hline A43 & 50,0 & Low \\
\hline A44 & 10,0 & Very low \\
\hline A45 & 70,0 & High \\
\hline A46 & 60,0 & Moderate \\
\hline A47 & 50,0 & Low \\
\hline A48 & 10,0 & Very low \\
\hline A49 & 10,0 & Very low \\
\hline A50 & 30,0 & Very low \\
\hline Average & 53,0 & Moderate \\
\hline
\end{tabular}




\section{Jurnal Inovasi Pendidikan IPA, 6 (2), 2020 - 213}

Aida Fikriyah, Bayu Sandika, Etistika Yuni Wijaya

Based on findings that were figured out in Table 2 and Figure 1, it can be assumed that the preservice science teachers in the topic biodiversity during distance learning under condition of covid-19 pandemic should be enhanced in every learning process. Therefore, various interactive learning situations also have to be implemented to improve students' comprehension on science topics. Those data also indicated that some students cannot answer the questions correctly, especially on questions with indicators giving examples, classifying, and explaining. Mostly students argued that those questions were difficult to answer since they were also not easy to comprehend.

Based on the observation during this study, pre-service science teachers also did not get ready during the distance learning process since they only get ready to attain the concepts from lecturer. They also argued that they did not prepare the material by reading the learning sources before joining the class. This phenomenon often occur in the class among every learner in which students as pre-service science teachers are used to be passive users rather than active users, therefore evaluating concept mastery should be conducted to ensure whether pre-service science teachers are ready to learn or not.

One of the learning outcomes that have to be concerned by educators is the students' concept mastery. A concept is defined as a mentality that represents a stimulus from students. Concept can also be assumed as a category of objects, symbols, ideas, and phenomenons with the same characteristics (Prabowo et al., 2020; Satriawan et al., 2019). Furthermore, concept can be acquired in two ways, namely: a) concept formation; acquisition of concepts before students learn about a material in learning process, and b) concept assimilation; acquisition of concept during and after learning process (Rahayu, 2017; Sadiqin et al., 2017).

As concept mastery is very important, educators have to provide effectively meaningful learning process so that pre-service science teachers are able to reach this easily. The theory of a meaningful learning process by Ausubel states that a meaningful learning is a process of connecting new information to relevant concepts that are already present in a students' cognitive structure (Arulogun et al., 2020; Tamimiya \& Suryadarma, 2019). The most optimal concept development can occur if the most general or inclusive elements of a concept are introduced first, then the more detailed and more specific elements of the concept are given afterward (Jeong \& González-Gómez, 2020; Rusli et al., 2020). Therefore, to develop pre-service science teachers' competence, concept analysis is needed to improve.

In addition, pre-service science teachers' concept mastery also includes, (1) self-concept: the shift from one student who is dependent on others; (2) experience: many experiences can become learning sources; (3) readiness for learning: students are well-prepared in carrying out a new task and challenging assignments; and (4) orientation during learning process: learning process should be developed from learning-centered to problem-centered (König et al., 2020; Rusilowati et al., 2015). According to those situations, pre-service science teachers should be involved in actively diagnosing their learning needs. Furthermore, students will feel engaged and motivated well to learn if they learn as what they need.

Findings of this study also indicates that mostly students reached low concept mastery. It can be assumed that one of factors that influence the low concept mastery is an internal factor from pre-service science teachers. Students as pre-service science teachers are merely memorizing the concept material without understanding the concept whether they know what does it mean or not. In addition, if they only memorize without comprehend the concepts, the concepts will not be long stored in the memory. So that, the concepts are easily to be forgotten.

To learn and develop concept mastery, learners have to transfer knowledge from working memory (where it is determinedly processed) to long-term memory (where it is stored and later recovered) (Fratiwi et al., 2019). Students have limited working memory capacities that can be stunned by complex cognitive tasks. Comprehending new ideas can be obstructed if students are challenged with too much information at once. In addition, making content obvious through cautiously stepped explanation, description, modeling, and examples can ensure that students are not flabbergasted (Gumilar \& Wardani, 2020; Saprudin et al., 2020). Content also should not be retained only from students because it is developmentally inappropriate. The way and the process of how students comprehend content material are developed, and educators have to ensure that learners are ready to study. If they are well-prepared, then the concept attainment is easy to reach.

Pre-service science teachers have to improve concept comprehension at an early development when they undergo thinking and learning process. As it is already stated that science concepts consists of a plenty of information, objects, principles, ideas, and activities, therefore concept mastery is very essential thing in learning process (Prabowo et al., 2020). However, it can generate huge problem if the 


\section{Jurnal Inovasi Pendidikan IPA, 6 (2), 2020 - 214}

Aida Fikriyah, Bayu Sandika, Etistika Yuni Wijaya

concepts that they understand are diverse from scientific considerations in which this phenomenon is referred to as misconception (Arulogun et al., 2020). This phenomenon should be minimized in order learners as pre-service science teachers can perform well in pedagogical knowledge.

In addition, if the concepts have been understood well, learners can apply the concepts actively in their daily life. By mastering science concepts well, pre-service science teachers are able to fully understand their own role in bringing the concepts in society and linking these concepts. Therefore, educators have to provide the varying experiences and prerequisites for learning in every learner's background. Educators also have to ensure that classroom instructional quality is active and critical, since it can provide the learning experience and opportunity to foster concept mastery on pre-service science teachers. To sum up, pre-service science teachers' concept mastery has to be enhanced continually during every distance learning process in order pre-service science teachers are able to understand science knowledge and enhance their concept mastery.

\section{CONCLUSION}

This study aims at evaluating pre-service science teachers' concept mastery in the topic of biodiversity during distance learning under circumstance of covid-19 pandemic. Although the current learning process is implemented in distance, students' concept mastery has to be evaluated well. According to the findings obtained in this study, it can be concluded that pre-service science teachers' concept mastery in the topic of biodiversity during distance learning under circumstance of covid-19 pandemic reached a score of 53.0 in which was categorized as moderate criteria. Therefore, their concept mastery has to be enhanced continually in every learning process in order pre-service science teachers are able to comprehend science concepts and develop their pedagogical skill.

\section{REFERENCES}

Afandi, A., Sajidan, S., Akhyar, M., \& Suryani, N. (2019). Development frameworks of the indonesian partnership 21st-century skills standards for prospective science teachers: A Delphi study. Jurnal Pendidikan IPA Indonesia, 8(1), 89-100. https://doi.org/10.15294/jpii.v8i1.11647

Arulogun, O. T., Akande, O. N., Akindele, A. T., \& Badmus, T. A. (2020). Survey dataset on open and distance learning students' intention to use social media and emerging technologies for online facilitation. Data in Brief, 31, 4-11. https://doi.org/10.1016/j.dib.2020.105929

Badriyah, N. L., Anekawati, A., \& Azizah, L. F. (2020). Application of PjBL with brain-based STEAM approach to improve learning achievement of students. Jurnal Inovasi Pendidikan IPA, 6(1), 88-100. https://doi.org/10.21831/jipi.v6i1.29884

Costa, P. D. da, \& Araujo, L. (2018). Quality of teaching and learning in science. In Joint Research Centre (JRC). https://doi.org/10.2760/8605

Fratiwi, N. J., Utari, S., \& Samsudin, A. (2019). Study of concept mastery of binocular K-11 students through the implementation of A multi-representative approach. International Journal of Scientific and Technology Research, 8(8), 1637-1642.

Glaze, A. L. (2018). Teaching and learning science in the 21st century: Challenging critical assumptions in post-secondary science. Education Sciences, 8(1), 1-8. https://doi.org/10.3390/educsci8010012

Goodsett, M. (2020). Best practices for teaching and assessing critical thinking in information literacy online learning objects. Journal of Academic Librarianship, 46(5), 102163. https://doi.org/10.1016/j.acalib.2020.102163

Gumilar, R. P., \& Wardani, S. (2020). The implementation of guided inquiry learning models on the concept mastery, scientific attitud, and science process skill. Journal of Primary Education, 9(229), 148-154.

Jeong, J. S., \& González-Gómez, D. (2020). Assessment of sustainability science education criteria in online-learning through fuzzy-operational and multi-decision analysis and professional survey. Heliyon, 6(8). https://doi.org/10.1016/j.heliyon.2020.e04706

König, J., Jäger-Biela, D. J., \& Glutsch, N. (2020). Adapting to online teaching during COVID-19 school closure: teacher education and teacher competence effects among early career teachers in 


\section{Jurnal Inovasi Pendidikan IPA, 6 (2), 2020 - 215}

Aida Fikriyah, Bayu Sandika, Etistika Yuni Wijaya

Germany. European Journal of Teacher Education, 43(4), 608-622.

https://doi.org/10.1080/02619768.2020.1809650

Kumari, T. A., Hemalatha, C., Ali, M. S., \& Naresh, R. (2020). Survey on impact and learning's of the online courses on the present era. Procedia Computer Science, 172, 82-91.

https://doi.org/10.1016/j.procs.2020.05.167

Littenberg-Tobias, J., \& Reich, J. (2020). Evaluating access, quality, and equity in online learning: A case study of a MOOC-based blended professional degree program. Internet and Higher Education, 47, 100759. https://doi.org/10.1016/j.iheduc.2020.100759

Mamun, M. A. Al, Lawrie, G., \& Wright, T. (2020). Instructional design of scaffolded online learning modules for self-directed and inquiry-based learning environments. Computers and Education, 144(September 2019), 103695. https://doi.org/10.1016/j.compedu.2019.103695

Müller, K., Prenzel, M., Seidel, T., Schiepe-Tiska, A., \& Kjærnsli, M. (2016). Science teaching and learning in schools: theoretical and empirical foundations for investigating classroom-level processes. In Methodology of Educational Measurement and Assessment (Issue December, pp. 423-446). https://doi.org/10.1007/978-3-319-45357-6_17

Nugroho, R. A., \& Suryadarma, I. G. P. (2018). Pengaruh servant leadership learning dengan concept mapping terhadap pemahaman konsep dan berpikir kritis siswa The effect of the servant leadership learning with concept mapping on the concept understanding and critical thinking students. Jurnal Inovasi Pendidikan IPA, 4(1), 114-127.

OECD. (2018). What 15-year-old students in Indonesia know and can do. Programme for International Student Assessment (PISA) Result from PISA 2018, 1-10.

Prabowo, S., Surjono, H. D., \& Prabowo, M. (2020). Improving virus lesson mastery by using webbased learning media. Proceedings of the International Conference on Online and Blended Learning 2019 (ICOBL 2019), January. https://doi.org/10.2991/assehr.k.200521.033

Rahayu, N. (2017). Pengaruh pembelajaran dengan pendekatan inquiry terhadap penguasaan konsep dan scientific skill materi sistem pencernaan. Jurnal Inovasi Pendidikan IPA, 3(1), 70. https://doi.org/10.21831/jipi.v3i1.9888

Rapanta, C., Botturi, L., Goodyear, P., Guàrdia, L., \& Koole, M. (2020). Online University Teaching During and After the Covid-19 Crisis: Refocusing Teacher Presence and Learning Activity. Postdigital Science and Education, 1-23.

Reimers, F., Schleicher, A., Saavedra, J., \& Tuominen, S. (2020). Supporting the continuation of teaching and learning during the COVID-19 pandemic. In $O E C D$.

Rosamsi, S., Miarsyah, M., \& Ristanto, R. H. (2019). Interactive Multimedia Effectiveness in Improving Cell Concept Mastery. Journal of Biology Education, 8(1), 56-61. https://doi.org/10.15294/jbe.v8i1.28154

Rusilowati, A., N, S. E., \& S., S. M. E. (2015). Developing of Science Textbook Based on Scientific Literacy for Seventh Grade of Secondary School. International Conference on Mathematics, 2015(Icmse), 42-45.

Rusli, R., Rahman, A., \& Abdullah, H. (2020). Student perception data on online learning using heutagogy approach in the Faculty of Mathematics and Natural Sciences of Universitas Negeri Makassar, Indonesia. Data in Brief, 29, 105152. https://doi.org/10.1016/j.dib.2020.105152

Sadiqin, I. K., Santoso, U. T., \& Sholahuddin, A. (2017). Pemahaman konsep IPA siswa SMP melalui pembelajaran problem solving pada topik perubahan benda-benda di sekitar kita. Jurnal Inovasi Pendidikan IPA, 3(1), 52. https://doi.org/10.21831/jipi.v3i1.12554

Saprudin, S., Liliasari, L., Setiawan, A., \& Prihatmanto, A. S. (2020). Optical gamification (OG); Serial versus random model to improve pre-service physics teachers' concept mastery. International Journal of Emerging Technologies in Learning, 15(9), 39-59. https://doi.org/10.3991/ijet.v15i09.11779

Satriawan, M., Liliasari, S., \& Setiawan, W. (2019). Wave energy concept mastery relate on creative thinking skills of the pre-service physics teachers in environmental physics lectures. Journal of Physics: Conference Series, 1157(3). https://doi.org/10.1088/1742-6596/1157/3/032044 


\section{Jurnal Inovasi Pendidikan IPA, 6 (2), 2020 - 216}

Aida Fikriyah, Bayu Sandika, Etistika Yuni Wijaya

Tamimiya, K. T., \& Suryadarma, I. G. P. (2019). Potensi lokal Gunung Ijen untuk pemahaman konsep dan berpikir kreatif pengurangan resiko bencana. Jurnal Inovasi Pendidikan IPA, 5(1), 117-128. https://doi.org/10.21831/jipi.v5i1.25702

van Rensburg, E. S. J. (2018). Effective online teaching and learning practices for undergraduate health sciences students: An integrative review. International Journal of Africa Nursing Sciences, 9(July), 73-80. https://doi.org/10.1016/j.ijans.2018.08.004

Widiyawati, Y., \& Nurwahidah, I. (2018). Elclivs berbasis inquiry untuk meningkatkan penguasaan konsep siswa tuna netra pada materi rangkaian listrik Elclivs-inquiry based to enhance visual impairment student conceptual understanding in electricity circuit topics. 4(2), 212-223. 